\title{
El jardinero fingido en la comedia lopeveguesca*
}

\section{The false gardener in Lope de Vega's plays}

\author{
Marcella Trambaioli \\ Università del Piemonte Orientale, Vercelli
}

RESUMEN: la máscara de jardinero fingido, determinación específica del tipo del noble disfrazado de villano, es frecuente sobre todo en el repertorio de la comedia lopesca de ambientación urbana; si en la acción principal el hortelano de amor corteja de incógnito a la dama, en la trama cómica el tipo dramático queda rebajado por su trato con labradores reales; alrededor de 1615 el Fénix, ya Belardo en el Romancero, llega a utilizar esta figura incluso como portavoz metateatral de sus instancias autopropagandísticas.

Palabras clave: Lope de Vega, jardinero fingido, disfraz, hortelano de amor, máscara rústica, autofiguración poética

ABSTRACT: the dramatic mask of the false gardener, one of the many types of noble disguised as a peasant, is specially frequent in Lope de Vega's urban comedy; if in the main plot the love gardener courts his lover taking profit of the disguise, in the comic plot the dramatic type is parodied thanks to his links with real peasants; about 1615, Lope, already masked as Belardo in the Romancero, makes use of this dramatic type as a spokesman of his personal courtly ambitions.

Keywords: Lope de Vega, false gardener, disguise, love gardener, peasant mask, poetic self-representation

\footnotetext{
* Entre hortelano de amor, máscara rústica y alter ego dramático.
} 
La figura del jardinero fingido no halla el espacio que le correspondería en la monumental monografía que Noël Salomon ha dedicado a lo villano en la comedia barroca española. Verdad es que, aun siendo muy exaustiva y documentada, la labor crítica del hispanista francés representa un punto de partida para ulteriores y necesarios enfoques. Lo ha puesto de relieve con acierto Catalina Buezo intentando ordenar las tipologías villanescas en relación con los diferentes subcódigos teatrales, pero ella tampoco se ha fijado en la figura que

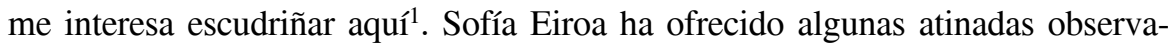
ciones acerca del falso jardinero en el teatro de $\mathrm{Tirso}^{2}$, y en las recientes jornadas burgalenses sobre Máscaras y juegos de identidad María Rosa Álvarez ha trazado un perfil de esta máscara rústica a partir del modelo quinientista del Don Duardos de Gil Vicente, centrando su análisis en El príncipe viñador de Vélez de Guevara y en La venganza de Tamar de Tirso ${ }^{3}$. Falta en cambio, que yo sepa, un estudio de la misma en la producción lopeveguesca, que por razones obvias representa el modelo paradigmático para su tratamiento en los demás dramaturgos auriseculares ${ }^{4}$. Dicha laguna crítica se debe sin duda al hecho de que este tipo teatral destaca en algunas de las comedias más desatendidas del inmenso repertorio del Fénix.

\footnotetext{
${ }^{1}$ Catalina Buezo, «Hacia una tipología del villano y lo villano en el teatro áureo», La comedia villanesca y su escenificación, Actas de las XXIV Jornadas de Teatro Clásico (Almagro, 1012 de julio de 2001), Felipe B. Pedraza Jiménez, Rafael González Cañal y Elena Marcello, eds., Almagro, Universidad de Castilla La-Mancha, Festival de Almagro, 2002, pág. 301, se limita a subrayar que: «el reiterado motivo del noble disfrazado de villano, que parece haber propiciado la introducción del lirismo en la comedia, responde a una moda literaria de utilización por parte de las clases pudientes urbanas de formas del arte popular y rural, no a una práctica social real».

${ }^{2}$ Sofía Eiroa, «Los villanos fingidos en Tirso de Molina: técnicas dramáticas y su representación», La comedia villanesca y su escenificación, cit., págs. 241-244; la estudiosa española toma en cuenta La venganza de Tamar, donde el protagonista finge ser hijo del hortelano, La huerta de Juan Hernández, en la cual Hernando se disfraza de jardinero para estar junto a su amada Laura, Quien da luego, da dos veces, donde Carlos, desterrado por el hermano, permanece al lado de su esposa secreta en hábitos de hortelano, y El pretendiente al revés, en la que otro Carlos asume el disfraz villano para cortejar a su dama; habría que añadir La fingida Arcadia, pieza donde Felipe aparece en hábitos de jardinero por amor de Lucrecia.

${ }^{3}$ María Rosa Álvarez Sellers, «Príncipes disfrazados y estrategias de pasión: Don Duardos de Gil Vicente, El príncipe viñador de Vélez de Guevara y La venganza de Tamar de Tirso de Molina», en M. L. Lobato, ed., Máscaras y juegos de identidad en el teatro español del Siglo de Oro, Madrid, Visor Libros, 2011, págs. 261-277; dicha estudiosa profundiza algunas sugerencias de un trabajo anterior de Maria Grazia Profeti, «I viaggi di un principe giardiniere», en M. J. de Lancastre, S. Peloso, U. Serani, R. Antonelli, eds., E Vós, Tágides Minhas: Miscellanea in onore di Luciana Stegagno Picchio, Viareggio, Mauro Baroni, 1999, págs. 523-540, que toma en cuenta otros eslabones de la cadena textual que del Don Duardos llega a una reescritura italiana de Giacinto Andrea Cicognini: Il principe giardiniero.

${ }^{4}$ En «Variaciones sobre el motivo del jardinero fingido en la escritura de Calderón, Moreto y su escuela dramática», en M. L. Lobato, ed., cit., págs. 95-111, tomo en cuenta las siguientes comedias: La señora y la criada y La fiera, el rayo y la piedra de Calderón, Hasta el fin nadie es dichoso de Moreto, El alcázar del secreto de Solís y Pasión vencida de afecto de Diamante.
} 
Las páginas que siguen pretenden rellenar, en alguna medida, esta casilla del capítulo del aristócrata disfrazado de labrador el cual, por cierto, comprende muchas y variadas determinaciones, tales como la de la dama que va persiguiendo al amante infiel en atuendos aldeanos, la del noble que huye de la corte buscando refugio en el campo por alguna grave cuestión personal o política, y la del héroe-villano forzado a vivir en un estado de simpleza, desconociendo sus ilustres orígenes 5 .

Al igual que los demás disfraces aldeanos, el del jardinero fingido permite el desarrollo en la acción dramática de «la contraposición entre apariencia rústica y alma noble» para decirlo con Joan Oleza ${ }^{6}$, y en último análisis de la confusión típicamente barroca entre el ser y el aparentar, subrayada mediante el atuendo escénico. Este resorte conlleva una serie de juegos de espejos metateatrales y equivocaciones que ruedan alrededor de la suplantación de la personalidad sustentando la «scena en abyme» sobre la cual ha reflexionado Maria Grazia Profeti en las huellas de Cesare Segre ${ }^{7}$.

Como vamos a ver, su peculiar fisonomía se inserta en una tipología teatral que, salvo contadas excepciones, no corresponde a la comedia villanesca o a la

\footnotetext{
${ }^{5}$ Vid. Noël Salomon, Recherches sur le thème paysan dans la «comedia» au temps de Lope de Vega, Bordeaux, Institut d'Études Ibériques et Ibéro-Américaines de l'Université de Bordeaux, 1965, págs. 456-472; Donald McGrady, «Prólogo», Lope de Vega, Peribáñez y el Comendador de Ocaña, Barcelona, Crítica, 1997, págs. LXXI-LXXII: «a partir de cierto punto, aparece en el escenario otra clase de rústico, el labrador, o por mejor decir, un noble disfrazado de labrador, que viene huyendo de algún grave problema en la corte -un tipo que venía rodando desde antiguo, y que Lope había de introducir en unas ochenta comedias suyas [...] Estos nobles refugiados en el campo tienen mucho en común con los protagonistas de las comedias pastoriles, ya que unos y otros son vástagos de alcurnia que asumen el atavío campestre»; a propósito del «héroevillano», véase Fausta Antonucci, El salvaje en la comedia del Siglo de Oro. Historia de un tema de Lope a Calderón, Pamplona, Toulouse, RILCE, LESO, 1995, págs. 108 sigs.; de manera específica la estudiosa italiana apunta: «el personaje en cuestión se ha criado en el campo, ya no en la selva y junto a las fieras como el salvaje; a veces se cree hijo de algún campesino, otras veces desconoce por completo el secreto de su nacimiento, y entonces a menudo la incertidumbre acerca de su identidad le causa resquemores y desasosiego. El conflicto que pone en marcha la intriga, o contribuye a su desarrollo, surge porque el personaje no acepta las limitaciones que su colocación social le impone, y aspira a más: ya sea por ambición y noble soberbia, ya sea porque el amor lo impulsa a elevarse por encima de su condición humilde» (pág. 108).

${ }^{6}$ Joan Oleza, «La propuesta teatral del primer Lope de Vega», Cuadernos de Filología, III, 12, 1981, pág. 172.

${ }^{7}$ Cesare Segre, «Shakespeare e la «scena en abyme», en Teatro e romanzo, Torino, Einaudi, 1984, págs. 51-60, y Maria Grazia Profeti, «Essere vs apparire nel teatro barocco», en Dialogo. Studi in onore di Lore Terracini, I, Inoria Pepe Sarno, ed., Roma, Bulzoni Editore, 1990, págs. 548-549: «Si potrà a questo punto cercare di schematizzare i meccanismi scenici che nella commedia aurea sostengono il gioco dell'essere e dell'apparire. Il più macroscopico è quello dell'organizzazione meta-spettacolare, il gioco del teatro nel teatro [...] Un vertiginoso gioco di specchi; l'ultimo dei quali è l'occhio dello spettatore. Alla «scena en abyme», per prendere a prestito la definizione di Cesare Segre, si intreccia il motivo del travestimento, parte integrante del meccanismo scenico che sostiene la trama».
} 
comedia palatina ${ }^{8}$, sino a la pieza de ambientación urbana ${ }^{9}$. En realidad se trata de obras híbridas desde el punto de vista del subgénero teatral ${ }^{10}$, ya que presentan cuadros de espectacularidad autónoma de ambiente arcádico o palatino, hecho que se relaciona con su destino representacional cortesano ${ }^{11}$.

Así pues, el temporáneo rebajamiento del aristócrata a jardinero se produce en el interior de un palacio ubicado casi siempre en una ciudad española, donde el galán se ha introducido con el engaño para cortejar a la dama de la cual se ha enamorado ${ }^{12}$. De esta manera, Lope consigue injertar el mundo literario de la Arcadia - tanto rústica como refinada - en un ambiente familiar y reconocible, creando una contaminación original entre lo urbano y lo villanesco. Esta tendencia compensa, al menos en parte, la escasez de comedias pastoriles que se evidencia tras la época primeriza ${ }^{13}$.

${ }^{8}$ Acerca del disfraz pastoril en la comedia palatina observa Oleza, «La propuesta teatral del primer Lope de Vega», cit. pág. 171: «Las comedias palatinas encuentran [...] un eje temático importante en la problemática de la identidad, la máscara, el disfraz. El marco general es siempre el mismo: Desestabilización del orden - Aventuras de la identidad oculta - Restablecimiento del orden y Recuperación de la identidad».

${ }^{9}$ Prefiero utilizar el marbete de «comedia de ambientación urbana» como sinónimo de «comedia de capa y espada», siendo la «comedia urbana» a secas la de la primera época de Lope de Vega; en todo caso, no hay uniformidad terminológica en la bibliografía crítica correspondiente; cfr. Ignacio Arellano, Convención y recepción. Estudios sobre el teatro del Siglo de Oro, Madrid, Gredos, 1999, pág. 76, nota 2: «La denominación de «comedia urbana» respeta el rótulo de las jornadas de Almagro, en las que se discutía este aspecto lopiano intentando delimitar el subgénero. Es útil conservar tal denominación, porque, como se verá, todavía no podemos llamar plenamente «comedias de capa y espada» a esta clase»; Stefano Arata, «Introducción», en Lope de Vega, El acero de Madrid, Madrid, Castalia, 2000, pág. 25, nota 25: «Es díficil decir cuándo comedias de indefinida ambientación urbana se fijaron en ese subgénero que llamamos de capa y espada. El teatro de Lope de Vega es un sistema en continua evolución y los límites genéricos son muy inestables. El hecho de que unas mismas comedias hayan sido denominadas con marbetes diferentes (urbanas, de capa y espada, de enredo, de costumbres contemporáneas, de carácter, etc.) refleja la dificultad de la crítica a la hora de definir un fenómeno tan proteico [...] Con fines esencialmente prácticos, voy a utilizar el término de «comedia urbana» para indicar todas esas piezas que tienen una indefinida ambientación urbana, limitando el término «comedia de capa y espada» para ese conjunto de obras, escritas a partir de los primeros años del reinado de Felipe III, que presentan rasgos de género más definidos y homogéneos».

10 Tiene toda la razón Antonucci, cit., pág. 118, cuando habla de la «ardua cuestión de la clasificación tipológica de las obras teatrales» en relación con el estudio temático.

11 Acerca de la «cortesanización» del subgénero de la comedia de ambientación urbana, vid. algunas observaciones e indicaciones bibliográficas en Marcella Trambaioli, "“Aquí, Senado, se acaba...": normas implícitas y rasgos dramáticos del teatro de cámara de Lope de Vega», en G. Poggi y M. G. Profeti, eds., Norme per lo spettacolo / Norme per lo spettatore. Teoria e prassi del teatro intorno all "Arte Nuevo”, Firenze, Alinea Editrice, 2011, págs. 185-198; sobre este aspecto específico estoy elaborando una monografía: La épica de amor en las comedias de ambientación urbana de Lope de Vega, subgénero del teatro cortesano.

12 Como tipología de engaño típico de la comedia cómica, el disfraz de jardinero forma parte de la categoría del «mudar la identidad», siguiendo la clasificación de José Roso Díaz, Tipología de engaños en la obra dramática de Lope de Vega, Cáceres, Universidad de Extremadura, 2002, págs. 129 sigs.

${ }^{13}$ Cfr. «La tradición pastoril en la comedia de Lope de Vega», J. L. Canet Vallés, ed., Teatro y prácticas escénicas. II: La comedia, José Luis Canet Vallés, ed., London, Tamesis, 1986, págs. 325-343. 
El análisis propuesto seguirá el orden cronológico para evidenciar cómo va cambiando la funcionalidad del tipo teatral en cuestión en las distintas fases de la producción dramática lopesca.

\section{El JARDINERO DE AMOR EN UNA COMEDIA DE LA ETAPA JUVENIL: EL SOL- DADO AMANTE}

La primera de las piezas lopeveguescas en que he conseguido aislar el tipo dramático en cuestión, El soldado amante ${ }^{14}$, pertenece al subgénero palatino. Se trata de una comedia temprana - Morley y Bruerton la fechan alrededor de 1593-95 15 — que se halla incluida en el listado de las ocho obras con el cual se cierra El peregrino en su patria ${ }^{16}$. Sabido es que este libro, pensado para un público culto, queda atravesado por toda una red de estrategias de defensa y autopromoción de Lope; parece sensato, pues, pensar que las comedias citadas en semejante contexto, que confunde la realidad de los festejos monárquicos de $1599^{17}$ con las celebraciones ficticias por la boda final de los protagonistas de la novela, se hayan compuesto para unas representaciones cortesanas ${ }^{18}$.

En la fábula dramática el viejo rey de Escocia, ofendido por el aborrecimiento de Rodiana, la bella reina de Holanda, envia a su hijo Clarinarte a prenderla con la fuerza. El príncipe se enamora de la soberana holandesa a través de un retrato, que forma parte del botín de guerra: es el pastor Belardo, único superviviente de la batalla, quien le revela su identidad. El hecho de que éste sea jardinero de la huerta regia le sugiere a Clarinarte cómo introducirse en el reino enemigo, y el I acto termina con su atrevida resolución: «Deste villano tomaré la forma» (pág. 564). La estratagema funciona al punto que Rodiana, tras escuchar su mentida relación de la batalla, le regala un anillo, objeto sim-

${ }^{14}$ Cito por El soldado amante, Obras de Lope de Vega, tomo IX, Emilio Cotarelo, ed., Madrid, R.A.E., Tipografía de Archivos, 1930, págs. 552-589.

15 Para la datación de las comedias de Lope, salvo indicación contraria, remito a Griswold Morley y Courtney Bruerton, Cronología de las comedias de Lope de Vega, Madrid, Gredos, 1968.

${ }^{16}$ Lope de Vega, El peregrino en su patria, Juan Bautista Avalle-Arce, ed., Madrid, 1973, pág. 481: «La segunda, Alcaraz, único representante y de sutil ingenio, llamóse El soldado amante»; el autor de comedia mencionado es Diego López de Alcaraz; el propio Lope, insertando la pieza en la Parte XVII indica «Representola Osorio, autor antiguo, y famoso» (en Thomas E. Case, Las dedicatorias de Partes XIII-XX de Lope de Vega, Madrid, Castalia, Department of Romance Languages, University of North Carolina, 1975, pág. 56).

${ }^{17} \mathrm{Cfr}$. Avalle-Arce, El peregrino en su patria, cit., pág. 14.

${ }^{18}$ Llego a estas mismas conclusiones en el caso de otra de las ocho comedias mencionadas en el cierre del Peregrino, La fuerza lastimosa, en Marcella Trambaioli, «Lope de Vega y la casa de Moncada», Criticón, 106, 2009, págs. 12-13. 
bólico del futuro enlace matrimonial, y le da acogida en su palacio ${ }^{19}$. El príncipe se presenta así al jardinero de la corte holandesa como «labrador de fama» (pág. 568), pero su habla distinguida y sus refinados modales llevan al hortelano a sospechar que sea de ilustre abolengo ${ }^{20}$. En su respuesta, aun intentando ofrecer al labrador datos verosímiles, no abandona el lirismo apropiado a su condición de galán enamorado, y finge llamarse Rodiano, versión masculina del nombre de la Reina, remitiendo de forma oblicua al topos neoplatónico de la transformación de los amantes ${ }^{21}$.

Al mismo tiempo, para otorgar al príncipe algún rasgo de su tosca máscara, el dramaturgo hace que la hija del jardinero, Pirena, se enamore de él en el acto, pretendiendo el casamiento sin dilación. Obligado por su disfraz, Clarinarte tiene que llevar la corriente a la joven desenvuelta, desesperándose en aparte: «Ay, princesa de mi vida! / ¿Adónde llevas perdida / mi vida, crédito y honra?» (pág. 570). De todas formas, esta esbozada situación cómica no se desarrolla ulteriormente a lo largo de la acción.

Estando en la corte, el príncipe tiene la oportunidad de aparecer de noche a la Reina en sus hábitos de soldado, como si se tratara de una sombra misteriosa. ${ }^{22}$ Jugando dramáticamente con su doble identidad consigue que Rodiana se interese por el desconocido pretendiente. El ambiguo intercambio dialéctico entre los dos se realiza lírica y escénicamente mediante el recurso al eco poético con repetición consecutiva ${ }^{23}$ en un soneto que la pareja protagonista recita sola en el tablado, mientras el Conde va buscando al inefable soldado por toda la huerta.

De nuevo en hábitos de jardinero, Clarinarte se entrevista con la Reina, quien lo interroga sobre su enemigo; así enmascarado logra comunicarle que el príncipe, es decir él mismo, se ha enamorado de ella gracias a su efigie pintada:

Él os ama a toda ley, aunque parece enemigo;

19 «Tú, dichoso jardinero, / que de la muerte escapaste / de aquese tirano fiero, / [...] / toma este anillo en señal / de que no temo a los hados / [...] / y en la huerta de mi casa, / mientras esta furia pasa, / harás el mismo ejercicio» (pág. 567).

20 «Bien se ve vuestra nobleza, / y pésame que a pobreza / y a miseria hayáis venido. / ¿Qué hacienda se os ha perdido?» (pág. 569).

${ }^{21}$ Vid. Guillermo Serés, La transformación de los amantes. Imágenes del amor de la antigüedad al Siglo de Oro, Barcelona, Crítica, 1996.

22 Así Rodiana describe al Conde, enamorado en balde de ella, la misteriosa aparición: «una espantable sombra, un hombre armado, / que el amante soldado dijo que era» (pág. 573).

23 Vid. Marcella Trambaioli, «Valores poéticos y funciones escénicas del eco en las fábulas mitológicas de Calderón», Deseo, sexualidad y afectos en la obra de Calderón, Duodécimo Coloquio Anglogermano sobre Calderón (Leipzig, 14-18 de julio de 1999), Manfred Tietz, ed., Stuttgart, Franz Steiner, 2001, pág. 182: «Lope de Vega no recurre tan frecuentemente a esta técnica, ni siquiera en sus fábulas mitológicas y de escenario pastoril, aunque sí compuso varios sonetos en eco, insertando algunos en sus comedias». 
cree[d]me aquesto que os digo

como palabra de rey. (pág. 577)

Por su parte, Rodiana no duda ni un instante de la buena fe del hortelano, confiando en su rústica simpleza: «Eres bastante testigo, / porque tan groseros paños / no pueden cubrir engaños» (pág. 577). Lo cual nos hace constatar, si hubiera falta, que para el personaje barroco la apariencia suele determinar el estatuto social, y que el ocultamiento de la identidad transforma la famosa frase «soy quien soy» ${ }^{24}$ en «soy lo que aparento».

El acto intermedio se acaba con una situación dramática muy parecida a la que cierra el primero, creando un paralelismo estructural: la Reina confiesa al jardinero fingido haberse prendado de oídas del príncipe; sin embargo, no fiándose de la fama, desea verle en persona de incógnito, expresando la intención de ir a su campamento en atuendos rústicos:
Mas como suele mentir
la fama que suena más, no me ha de engañar jamás
el sentido del oír.
Yo lo he remitido al ver;
en este traje contigo
he de ver a mi enemigo. (pág. 577)

Sin embargo, mientras Clarinarte conoce su identidad, ella sigue ignorando la del vástago escocés.

El último acto se abre con ambos protagonistas vestidos de labradores; el galán, actuando como el pastor fino de la tradición arcádica, hace hincapié en la belleza de la dama mediante referencias a la culta tradición pastoril-mitológica. $^{25}$ Observemos que el doble disfraz remite literaria y escénicamente al mencionado motivo de la recíproca metamorfosis de los amantes, tal como el propio Clarinarte subraya en un lírico soliloquio:

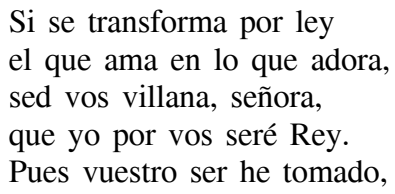

${ }^{24}$ Cfr. Leo Spitzer, «Soy quien soy», Nueva Revista de Filología Hispánica, 1, núm. 2, 1947, págs. 113-127.

${ }_{25}$ «Eres villano perfeto, / y en el donaire tan solo, / que vences al mismo Apolo / cuando fue pastor de Admeto. / [...] / Si eran ansí los pastores / de las edades primeras, / ¿qué mucho que hasta las fieras / rindiesen de mal de amores?» (pág. 577). 
y vos el que yo tenía, bien arguya, reina mía, que estoy en vos transformado. (pág. 582)

No obstante, la diferente consciencia de los hechos que tienen los dos protagonistas es causa de un malentendido que corre el riesgo de echar a perder la apuntada ventaja del príncipe: el caso es que Rodiana, cuando llega a la presencia del hijo del rey escocés, percatándose de su semejanza física con el jardinero, queda negativamente impresionada:

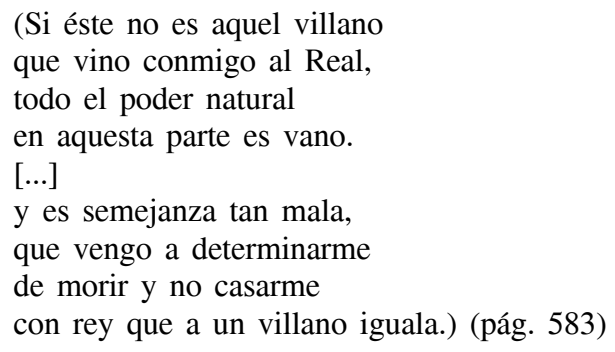

Se confirma, pues, que para la Reina la máscara, es decir, la apariencia con la cual ha conocido al príncipe coincide con la esencia fingida, impidiéndole apreciar su persona por lo que es.

Tras dejarla volver a su reino, Clarinarte la sigue vestido de nuevo de labrador. La Reina sigue dudando que el jardinero y el príncipe sean la misma persona; en definitiva, él paga por el hecho de haberla engañado con la verdad, según admite sin quererlo la propia Rodiana: «Que me engaña la verdad. / ¿Si es él? ¿No? ¿Sí?» (pág. 587). La confusión llega a su ápice cuando la mujer ordena al Conde que mate al labrador por espía, pero in extremis lo salva, reconociendo su equivocación, y acepta casarse con el soldado amante celebrado en el título de la obra.

\section{El JARdinero de AMOR y Su doble BuRlesco en LOS PONCES DE BARCE- LONA}

Los Ponces de Barcelona (1610-1615, prob. 1610-1612) ${ }^{26}$, pese a la datación que se deduce del análisis de la versificación, parece una obra temprana por su hibridismo genérico y por elementos teatrales tales como «el numeroso

\footnotetext{
${ }^{26}$ Cito por Los Ponces de Barcelona, Marcella Trambaioli, ed., en Comedias de Lope de Vega. Parte IX, Barcelona-Lleida, PROLOPE, UAB-Editorial Milenio, 2007, vol. III, págs. 1.055-1.154.
} 
reparto que incluye varias comparsas, la patente influencia de un canovaccio de la Commedia dell'Arte, el puntual paralelismo con otra pieza primeriza, La mocedad de Roldán, el tema autobiográfico relacionado con Isabel de Urbina y el recurso a la figura de la madre» ${ }^{27}$.

El II y el III acto de esta comedia de ambientación ciudadana destacan por la presencia de dos falsos jardineros, si bien muy distintos en cuanto a su caracterización y función actancial.

El público en el acto de apertura ha asistido al nacimiento turbulento de Pedro, vástago del noble Pedro Ponce y de Lucrecia, hija de un pobre pintor. La guerra despiadada que el tiránico Dionís Ponce les ha declarado obliga al hijo a escaparse y a la nuera a vivir, sirviendo en traje humilde, en casa de un generoso amigo del viejo tacaño.

Al principio del acto II han pasado más de veinte años y de Pedro Ponce, prisionero en tierra otomana, no se sabe nada. El joven Pedro, quien se ocupa de cuidar la huerta del palacio, y Serafina, hija de su protector, se aman sin atreverse a confesar su recíproca pasión por la aparente diferencia de clase social; sólo la vuelta de Ponce padre con la consiguiente agnitio final, según el modelo homérico del regreso de Ulises a Ítaca ${ }^{28}$, consentirá el matrimonio entre los dos enamorados.

Para complicar el enredo a la espera del feliz desenlace, Lope inserta en las dramatis personae dos opositores de la joven pareja: por un lado, Lucrecia, quien actúa como madre castradora, mostrando todas las incongruencias de su tipo teatral $^{29}$; por otro, don Julio que se introduce en casa de Serafina disfrazado de jardinero. Por consiguiente, el joven Pedro y el noble de Aragón se enfrentan como rivales amorosos con la misma máscara rústica, aun partiendo de dos supuestos diametrales: el primero ignora su ilustre identidad, mientras el segundo recurre al engaño para pretender a la dama. Analicemos las respectivas caracterizaciones.

Pedro, pese a que todos suponen que es hijo de una criada, muestra un brío y una gallardía dignos del noble que es. Fabricio, prendado en balde de Lucrecia, lo define con admiración «¡Gallardo mozo!» (v. 998, pág. 1092), y su rival, viéndolo por primera vez, comparte el juicio positivo del criado: «Cara de hombre noble tiene» (v. 999). Además, como todos los aristócratas forzados a vivir en estado rústico desconociendo su origen, Pedro se porta con la arrogancia y altivez de un noble vástago; en la misma macrosecuencia, cuando ve a

27 Marcella Trambaioli, «En torno al doble estatuto dramático de Lucrecia en Los Ponces de Barcelona de Lope de Vega», Theatralia, XII, Homenaje a Maria Grazia Profeti, 2010, págs. 96-97.

${ }^{28}$ Remito a mi análisis de los motivos de épica de amor enhebrados en la acción y en el lenguaje poético de la comedia en mi citada monografía en preparación.

29 Vid. al respecto Trambaioli, «En torno al doble estatuto dramático de Lucrecia en Los Ponces de Barcelona de Lope de Vega», cit. 
don Julio en el palacio, comenta impaciente y celoso: « ¿Siempre este nuestro jardín / han de ocupar forasteros?» (vv. 1002-1003, pág. 1092). También, usa el lenguaje elevado propio de su alcurnia; por ejemplo, ante las fuentes del jardín expresa sus sentimientos amorosos con las tonalidades líricas de un soneto petrarquista. Cierto es que en ningún momento presenta rasgos negativos o chabacanos propios de su humilde condición temporánea, y en la trabazón de épica amorosa de la pieza desempeña el papel de Telémaco. En definitiva, Pedro es un héroe-villano que vive en un palacio ciudadano desposeído de su estatuto aristocrático; por lo mismo, el espacio dramático en que se mueve y su ignorancia con respecto a su distinguido abolengo no le imponen la máscara rústica del aldeano, sino la figuración refinada del jardinero de amor.

Por lo que respeta a Don Julio, si bien al final le toca el rol de galán suelto, tampoco queda retratado en términos realmente negativos, probablemente por llevar un apellido tan ilustre como el de Aragón ${ }^{30}$. Adviértase que la pieza debió de representarse en un contexto nobiliario con la probable asistencia de algún miembro de aquella dinastía ${ }^{31}$. Con todo, su doble rebajado sí presenta algún aspecto risible. En primer lugar, Domingo es un nombre recurrente para designar al bobo rústico o al figurón ${ }^{32}$. En segundo lugar, en una ocasión resulta tildado de «bestia», quedando animalizado en el correspondiente nivel cómico-burlesco al cual pertenece su tipo teatral. Esto ocurre cuando Serafina, tras abrazar a Pedro, se percata de su presencia y dice en aparte al enamorado: «(Pedro, con vergüenza voy. / Remedia mi honor, despide / esa bestia de mi casa.)»(vv. 1773-1775, pág. 1111) ${ }^{33}$. Es patente que Serafina lo evalúa a partir

${ }^{30}$ Cfr. Marcella Trambaioli, «El galán suelto y el figurón en Los Ponces de Barcelona de Lope de Vega», Nueva Revista de Filología Hispánica, LVI, núm. 2, 2008, pág. 500: «diríamos que don Julio de Aragón es tal vez el galán suelto más alejado del figurón que haya salido de la pluma de Lope, por lo menos, de los que se han identificado hasta ahora. Es como si el dramaturgo, en Los Ponces de Barcelona, hubiera realizado una difracción del galán suelto en varios personajes distintos no sólo para brindarnos toda la gama posible de matices — desde el tipo 'serio’ (Julio) hasta el proto-figurón (Marín), pasando por la figura del donaire (el gracioso Gonzalo) que da voz a las instancias meta-textuales de la escritura lopeveguesca-, sino también para evitar el tener que atribuir al personaje elevado las facetas risibles del tipo dramático que nos ocupa».

${ }^{31}$ En ibíd. recorto y analizo todos los elementos que remiten a la factura y destino cortesanos de la pieza; más en general, sobre la definición y descripción del corpus del teatro de cámara del Fénix; véase Trambaioli, «Aquí, Senado, se acaba...»: normas implícitas y rasgos dramáticos del teatro de cámara de Lope de Vega», cit.

${ }^{32}$ Cfr. Jean-Raymond Lanot, «Para una sociología del figurón», Risa y sociedad en el teatro español del Siglo de Oro, Paris, Éditions du C.N.R.S., 1981, págs. 134-135: «Los nombres de los figurones también merecen alguna atención. El más frecuente es Cosme [...] En cuanto a Lorenzo, plebeyo doble de Lauro y Laurencio, es nombre de alcaldes, de hidalgos y villanos y también del convencional tonto de entremés. Demás nombres como Blas, Gil, Domingo, Lucas suenan infaliblemente a rústico bobo, sea del entremés, sea, más a menudo, de la comedia».

${ }^{33}$ Lanot, «Para una sociología del figurón», cit., p 137, ha destacado oportunamente «la recuperación por la comedia de figurón del trillado tema del rústico bobo asimilado a las bestias con que vive». 
de su máscara, al igual que la reina de Holanda juzga al príncipe disfrazado en El soldado amante. Por lo mismo, la bestia no es don Julio, sino el Domingo fingido. Diríase que en este caso la figura del jardinero produce un rebajamiento del personaje noble debido a que éste oculta su identidad con malicia y está destinado al fracaso amoroso.

\section{El HORTELANO COMO MÁSCARA AUTORIAL EN LA ETAPA MADURA}

En El abanillo (1612-1618, probablemente hacia 1615) ${ }^{34}$, comedia de capa y espada con una doble ambientación urbana, gran parte de las macrosecuencias teatrales se desarrollan en Barcelona, pero, al principio y al final, el espacio dramático coincide con la Nápoles española. Dos de los nombres femeninos remiten a las flores primaverales: Florela se llama el primer amor perdido del conde Celio $^{35}$, y Clavela se apellida la prima de Estefanía, la dama de la cual el Conde se prenda en la urbe catalana.

Al principio del acto II, que se abre en el hermoso jardín de la casa de Estefanía, el galán protagonista sale acompañado por Fabio, en hábito de labrador. Con este disfraz, consigue rondar a la dueña del palacio, pero ésta no es la única ficción a la cual recurre a lo largo de la acción dramática, puesto que para no revelar su verdadera identidad en Barcelona usa el nombre postizo de Fineo.

Dado que la dama, si bien ignora la verdadera identidad del noble partenopeo, sabe que se trata de un ilustre personaje, la estratagema de la máscara de hortelano en esta comedia no pasa de ser un pretexto episódico para elaborar un fragmento lírico refinado. Bien mirado, en esta pieza nobiliaria ${ }^{36}$, la figura del jardinero fingido reviste una función meramente decorativa, sin llegar a vincularse estrechamente a la acción, pero en otras comedias coetáneas llega a personificar al mismo dramaturgo.

\subsection{Los ramilletes de Madrid}

En Los ramilletes de Madrid, pieza compuesta para alguna función particular en el marco de los festejos para las dobles bodas dinásticas de $1615^{37}$, el

\footnotetext{
${ }^{34}$ He consultado la obra por El abanillo, Obras de Lope de Vega, III, Emilio Cotarelo, ed., Madrid, R.A.E., 1917, págs. 1-32.

${ }^{35}$ Así se queja Celio al principio de la comedia, hablando con el criado Roberto: «Salió Florela de aquí, / llevome el alma Florela; / casose, mi bien perdí» (pág. 1).

36 Acerca de la factura y contexto representacional nobiliarios de la comedia, véase Trambaioli, «Lope de Vega y la casa de Moncada», cit., págs. 31-33.

${ }^{37}$ Cito por Los ramilletes de Madrid, Obras de Lope de Vega, Obras dramáticas, XIII, Emilio Cotarelo, ed., Madrid, R. A. E., 1930, págs. 469-504; sobre la coyuntura cortesana en que se
} 
tipo del hortelano adquiere unas sugerentes connotaciones autobiográficas: el protagonista, Marcelo, moviéndose en un enredo que elabora una densa red de referencias al tema de La Dorotea, es un alter ego dramático del Lope-Fernan$\mathrm{do}^{38}$. En el II acto él se disfraza de jardinero para acceder a la casa de Rosela; comprometiendo de esta forma la reputación de la dama, tendrá que casarse con ella, a pesar de estar todavía enamorado de Belisa.

El protagonista toma la resolución de introducirse en el palacio de la joven en una macrosecuencia dramática del acto inicial: hablando con la labradora Dominga, llega a saber que el viejo Otavio ha mandado comprar unas macetas de claveles y otras flores para «transformar en vergeles / ciertos balcones» (pág. 475). El acto intermedio empieza con el padre de Rosela comunicando su intención de hacer construir un jardín para que la hija pueda entretenerse sin salir de la casa. El galán sale vestido de jardinero y detalla a Otavio sus planes para organizar las flores y las plantas en cuadras cuidadosamente ordenadas. Notemos de paso que para galantear a una dama que lleva un nombre floral, la traza de Marcelo no podría ser más adecuada, considerando además que se enmarca en una pieza cuyo título remite a las flores primaverales.

Los rústicos atuendos, de buenas a primeras, impiden a la joven reconocer al caballero que había encontrado en el Prado, pero sus refinados y líricos requiebros la hacen vacilar sobre su identidad: «¿Qué es lo que decís, Andrés? / ¿Cómo habláis tan cortesano? / ¿Sois caballero, o villano?» (pág. 481). Marcelo, a diferencia que el príncipe en El soldado amante, se revela en seguida a su amada, confesándole las razones de su ocultamiento:

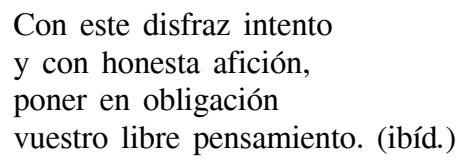

Pero Rosela tiene un hermano, el Alférez Lisardo, que es un acérrimo enemigo de Marcelo desde cuando los dos habían tenido una pendencia sirviendo como soldados en Flandes. El disfraz de jardinero no le sirve para camuflarse ante el Alférez quien lo reconoce sin más:

redacta la obra, vid. Marcella Trambaioli, «Una pre-Dorotea circunstancial de Lope de Vega: Los ramilletes de Madrid. II. Las polémicas literarias y la dimensión política», Criticón, 96, 2006, págs. 139-152.

${ }^{38}$ Cfr. Marcella Trambaioli, «Una pre-Dorotea circunstancial de Lope de Vega: Los ramilletes de Madrid. I. Análisis estructural», El Siglo de Oro en escena. Homenaje a Marc Vitse. [Anejo de Criticón, 17], Odette Gorsse y Frédéric Serralta, eds., Toulouse, Presses Universitaires du Mirail, Conserjería de Educación de la Embajada de España en Francia, 2006, págs. 1.037-1.048. 


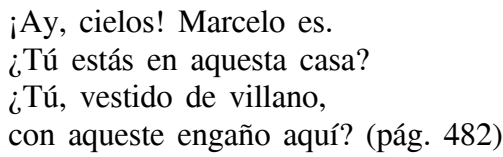

La máscara aquí funciona, pues, sólo de cara al personaje femenino en cuanto figura estilizada del noble enamorado. Fineo, amigo de Lisardo y pretendiente de la hermana del mismo, impide el desafío porque Marcelo no lleva armas y le ampara con caballerosidad. En todo caso, el protagonista, no estando realmente enamorado de Rosela, se declara dispuesto a salir del palacio para evitar mayores inconvenientes, volviendo a cortejar a Belisa: «Antes me vuelvo a mi jardín primero; / que ni peligro ni esperanzas quiero» (pág. 484).

Tras haber sido desenmascarado, ya no tiene sentido que Marcelo continúe ocultando su identidad; por consiguiente, la ficción del hortelano vuelve a revitalizarse en el texto dramático sólo a nivel jocoso cuando la desilusionada Rosela y su criada Clara revelan la traza del galán a Otavio, quien no había caído todavía en la cuenta:

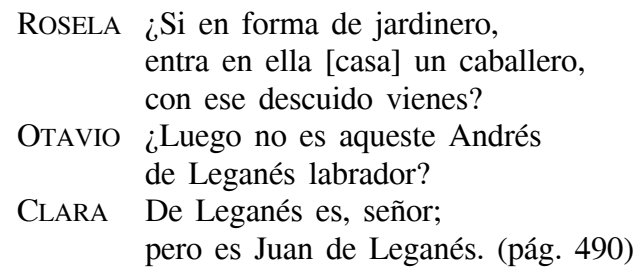

Juan de Leganés es el nombre de un loco madrileño que se convirtió en una personilla risible de la literatura burlesca coetánea; Lope lo menciona también en una pieza relativamente temprana, El ingrato arrepentido (1598-1603), como sinónimo de loco por amor ${ }^{39}$. A mi modo de ver, en el soneto satírico «Por tu vida, Lopillo, que me borres», Góngora atribuye a Belardo, la famosa máscara pastoril del Fénix, un adjetivo que evoca con sorna a dicho loco: «iOh brazos leganeses...» ${ }^{40}$.

Pues bien, en Los ramilletes de Madrid, al igual que en todas las piezas compuestas para un contexto representacional cortesano, Lope de Vega se pinta

\footnotetext{
${ }^{39}$ El criado Tancredo dice a Albano: «Basta, que te ha vuelto amor / otro Juan de Leganés», y luego explica: «[...] era un hombre menguado, / sin género de sentido, / y por eso parecido / a cualquier enamorado, / que todos sois mentecatos / y andáis contando imposibles» (El ingrato arrepentido, Obras de Lope de Vega, VI, Emilio Cotarelo, ed., Madrid, R.A.E., 1928, pág. 516).

${ }^{40}$ Luis de Góngora, Sonetos completos, Biruté Ciplijauskaité, ed., Madrid, Clásicos Castalia 1987, pág. 261, v. 8; dicho sea de paso, si el autor de las Soledades estuviera aludiendo realmente a El ingrato arrepentido, dicha comedia remontaría al año de composición del soneto, es decir 1598.
} 
a sí mismo en unas figuras del cuadro teatral; en concreto, llega a proyectarse en tres personajes, de los cuales uno es el protagonista. Como he tenido la oportunidad de apuntar en un trabajo reciente

agigantando su figura en el centro del marco dramático, y multiplicando su imagen con un ingenioso pero también obsesivo juego de refracciones pictóricas, Lope parece jugar todas sus cartas como si del éxito del estreno de esta pieza dependiera todo su futuro ${ }^{41}$.

En 1615, el Fénix, teniendo la ilusión de estar a punto de conseguir el tan ambicionado puesto de cronista regio, vierte en sus comedias cortesanas todas sus energías y estrategias metateatrales para llamar la atención de los nobles y de la familia real, reivindicando sus méritos y promocionando su persona. Fijémonos en que una técnica documentada en la pintura renacentista y barroca es la del artista autorretratándose en figuras del conjunto pictórico connotadas negativamente: con el auto-rebajamiento, por así decirlo, el pintor pretende compensar el atrevimiento del autorretrato de cara al ilustre comitente/espectador. Es el caso de Miguel Ángel pintándose despellejado en el Juicio Universal, o de Gaspare Celio, retratándose en uno de los verdugos romanos de Jesús en Cristo inchiodato alla croce ${ }^{42}$. Por lo visto, para rebajar su máscara literaria Lope en esta comedia se apropia de la festiva comparación que el cisne andaluz le había dedicado en el soneto citado, lo cual en una obra plagada de críticas a la poesía de don Luis no deja de ser un orgulloso desafío.

A la luz de lo expuesto, el hortelano fingido forma parte del repertorio de máscaras literarias con las cuales el poeta va construyendo su personaje poético a lo largo y a lo ancho de su larga carrera artística, de acuerdo con sus estrategias de autopropaganda ${ }^{43}$. Nos lo confirma la fiesta cortesana El premio de la hermosura donde Lope se dirige al público palaciego para solicitar la plaza de cronista oficial por boca del jardinero Fabio. Las razones que llevan al Fénix a escoger al hortelano como alter ego lírico privilegiado, desde cuando crea al Belardo del Romancero, se relacionan con el hecho de que la materia pastoril, a

\footnotetext{
${ }^{41}$ Marcella Trambaioli, «Lope in fabula: el Fénix pintado por sí mismo en el marco dramático de su teatro cortesano», Eva Llergo e Inmaculada Osuna, eds., Cultura visual, oral y escrita en la España de los Siglos de Oro (II Seminario GLESOC, Universidad Complutense de Madrid, 27-28 de octubre de 2009), Madrid, Visor Libros, 2010, pág. 553.

42 Doy las gracias a la historiadora del arte Nicoletta Lepri de la Università di Firenze que me ha proporcionado estas informaciones.

${ }^{43}$ Cfr. Trambaioli, «Lope de Vega y la casa de Moncada», cit., pág. 8: «la literaturización de la existencia, lejos de ser el producto de mero exhibicionismo, apunta a una poliédrica conformación del disfraz literario del dramaturgo, en que el mito lírico se ajusta a las cambiantes estrategias políticas. Con lo cual, queda superado el planteamiento de antiguos estudios sobre los alter ego literarios de Lope a la luz de la sola proyección autobiográfica».
} 
partir de las Coplas de Mingo Revulgo, se vincula de manera privilegiada al gusto artístico y teatral de la corte ${ }^{44}$.

Por otra parte, el dramaturgo nos habla en muchos textos del esmero con que cuida su jardincito en la casa de la calle de Francos ${ }^{45}$, para insertarse a sabiendas en la tradición bucólica del libro-jardín ${ }^{46}$ de la cual, entre muchos modelos paradigmáticos, se había aprovechado Petrarca ${ }^{47}$.

\footnotetext{
${ }^{44}$ Cfr. Salomon, cit., págs. 441-442: «Il est probable que le travestissement rustique des événements et des personnes commença alors à se répandre dans les fêtes de palais d'Espagne car nous avons plusieurs témoignages de cette pratique dans des églogues politiques ou de circonstance à la fin du $\mathrm{XV}^{\mathrm{e}}$ siècle et au début du $\mathrm{XVI}^{\mathrm{e}}$ siècle. C'est ce goût aristocratique pour la fiction rustique qui aboutit d'abord - sous l'influence de l'Italie - au roman pastoral et à la pastoral dramatique puis - lorsque l'influence italienne diminua et que les traditions péninsulaires reprirent le dessus - à la «comedia» «villanesque» où le paysan est encore un noble travesti»; véase, entre muchos ejemplos, lo que el estudioso francés apunta a propósito del disfraz rústico de los protagonistas de El vaquero de Moraña de Lope de Vega: «Une fois encore le rôle du déguisement paysan en tan que procédé de divertissement aristocratique apparaît nettement et les deux aristocrates travestis, l'un en moissonoeur ou en vacher, l'autres en servante de ferme, sont les premiers à rire de leur livrée villageoise» (pág. 456); ver también Maria Grazia Profeti «Luogo teatrale e scrittura: il teatro di Juan del Encina», en La vil quimera de este monstruo cómico, Kassel, Università di Verona, Ed. Reichenberger, 1992, págs. 3-20.

45 Vid., por ejemplo, la dedicatoria de El verdadero amante a su hijo Lopito en Case, cit., pág. 104: «tengo, como sabéis, pobre casa, igual cama y mesa y un huertecillo cuyas flores me divierten cuidados y me dan conceptos», o el verso del soneto «Discúlpase el poeta del estilo humilde» de las Rimas humanas y divinas del licenciado Tomé de Burguillos, José Manuel Rozas y Jesús Cañas Murillo, eds., Madrid, Castalia, 2005, pág. 337, en que sintetiza con ligereza inimitable su caudal de riquezas materiales: «dos libros, tres pinturas, cuatro flores»; además, en la epístola «Al licenciado Francisco de Rioja», El jardín de Lope de Vega y otras epístolas, Obras selectas, II, Federico Carlos Sáinz de Robles, ed., Madrid, Aguilar, 1947, pág. 151, el poeta nos ofrece una lírica y bucólica descripción de su huertecillo: «oye de mi jardín la artificiosa / máquina donde vivo retirado, / si no virtuosa vida, nunca ociosa. / Yace en el centro de un ameno prado $[\ldots]$ ».

${ }^{46}$ Cfr. Aurora Egido, «Escritura y poesía. Lope al pie de la letra», Edad de Oro, XIV, 1995, pág. 129, nota 24: «Lope ve en el jardín la cifra poética y pictórica de las Metamorfosis, aludiendo a la costumbre de los jardineros de tallar fábulas en las plantas, como ocurría en el carmen granadino de Soto de Rojas [...] Téngase en cuenta toda la tradición bucólica y el aludido origen de la escritura en hojas de palma y en cortezas de árbol»; más en general, vid. Ernst Robert Curtius, «El libro de la naturaleza», Literatura europea y Edad Media Latina, México, Fondo de Cultura Económica, 1955, I, págs. 448-489.

47 En Le familiari escribe el poeta laureado: «Mi vedrei contento di un piccolo ombroso giardino e di una piccola casa» (Francesco Petrarca, Rime, Guido Bezzola, ed., Andrea Zanzotto, introd., Milano RCS Rizzoli Libri, 1976, pág. 23); al respecto subraya Zanzotto en la introducción de la ed. cit., pág. 7: «Petrarca giardiniere e botanico incantato e puntiglioso [...] maestro nel coltivare appunto il suo piccolo giardino»; pero la jardinería es una metáfora que bien se puede aplicar a la estructura del Canzoniere: «appunto un giardino curato fisicamente in ogni splendida minuzia» (pág. 9); acerca de la relación entre poesía y agricultura, véase Aurora Egido, «Jardínlibro» y «Libro-jardín», en Pedro Soto de Rojas, Paraíso cerrado para muchos, jardines abiertos para pocos, Madrid, Cátedra, 1993, págs. 22-46; sobre la compleja red de significados relacionados con el jardín literario, véase el estado de la cuestión crítica trazado por Miguel
} 


\subsection{Al pasar del arroyo}

Otra pieza que viene como anillo al dedo para ejemplificar la faceta metapoética del tipo dramático del hortelano es Al pasar del arroyo ${ }^{48}$, obra que, tal como Los ramilletes de Madrid, se compone en ocasión de los festejos dinásticos de $1615^{49}$. Se trata de una comedia de ambientación sólo parcialmente urbana, porque la mayor parte de la acción se desarrolla en la huerta de Barajas, a las puertas de la capital. Siguiendo una sugerencia de Arata, se podría quizás postular su estreno en la huerta del duque de Lerma $^{50}$, con el tópico juego de espejos del teatro cortesano entre el espacio dramático y el espacio de la representación.

En el enmarañado enredo de esta obra se mueven don Carlos, noble disfrazado de jardinero, Benito, labrador que en realidad es un hermanastro del primero, Jacinta, labradora que, asimismo, es hija secreta de un conde napolitano, y un figurante llamado Hortelano, el cual aparece de refilón al final del I acto para relatar como testigo de vista el episodio del encuentro entre los dos protagonistas: don Carlos salva de la furia de un toro a Jacinta, mientras la presunta aldeana está yendo a Madrid para asistir a la entrada triunfal de la primera esposa del futuro Felipe IV.

Don Carlos se prenda de la hermosa labradora, y para poder estar a su lado se sirve de una traza engañosa. Fingiendo que está huyendo de la capital por haber matado a un hombre en una riña, pide amparo a Benito, preguntándole:

\footnotetext{
Zugasti, «El jardín: espacio del amor en la comedia palatina. El caso de Tirso de Molina», en Homenaje a Frédéric Serralta. El espacio y sus representaciones en el teatro español del Siglo de Oro, Actas del VII Coloquio de GESTE (Toulouse, 1-3 de abril de 1998), Françoise Cazal, Christophe González y Marc Vitse, eds., Madrid/ Frankfurt am Main, Universidad de Navarra/ Iberoamericana/ Vervuert, 2002, págs. 586-594.

${ }^{48}$ Cito por Al pasar del arroyo, Comedias escogidas de frey Lope Félix de Vega Carpio, en Juan Eugenio Hartzenbusch, ed., Madrid, Atlas, 1946, vol. I, págs. 387-407.

${ }^{49}$ De manera específica, la comedia da cuenta metateatral de la entrada de Isabel de Borbón en Madrid, hecho que aconteció el 19 de noviembre de 1615; Morley y Bruerton, op. cit., pág. 66, indican 1616 como fecha de redacción y en efecto el poeta debió de redactar la obra entre finales de noviembre del año anterior y principios de enero.

${ }^{50}$ En la comedia se alude a los juegos de cañas y toros organizados en ocasión del ingreso triunfal de Isabel de Borbón; Stefano Arata, Textos, géneros, temas. Investigaciones sobre el teatro del Siglo de Oro y su pervivencia, en F. Antonucci, L. Arata y M. del Valle Ojeda, eds., Pisa, Edizioni ETS, 2002, págs. 214-215, a dicho propósito, señala que «el cruce entre la carrera de San Jerónimo y el Prado Viejo era un lugar privilegiado para torneos y espectáculos cortesanos. Se solía cerrar la plaza, con tablados y madera, para correr toros o caballos, y jugar al estafermo o a la sortija»; según apunto en «Las dobles bodas reales de 1615: el triunfo del Lope-personaje sobre el Lope-cortesano», Bulletin of Hispanic Studies, vol. 87, n. 7, 2010, pág. 765: «en este sentido, la referencia a las huertas del duque de Lerma en la bajada de los Jerónimos cabe leerla en términos metateatrales como el espacio donde posiblemente se representó la obra».
} 
«Si me visto de hortelano / ¿podré estar en esa huerta?» (pág. 396). A continuación, hablando con el criado Mayo, revela su verdadero intento: «De noche salir podremos / adonde a Jacinta hablemos» (ibíd.), y será el gracioso el que se encargue de informar a la mujer de la estratagema:

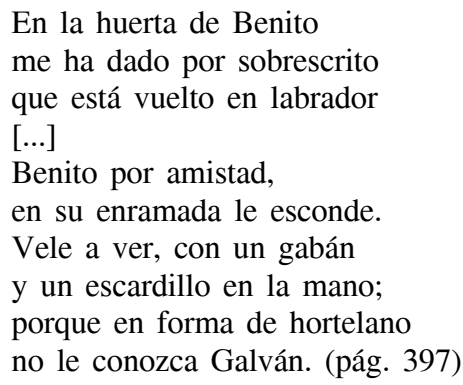

Don Luis, hermano de Lisarda, enamorada de don Carlos, a su vez está prendado de Jacinta y va a verla en la huerta; aquí da con el rival disfrazado de jardinero $\mathrm{y}$, sin reconocerlo, le pregunta por la protagonista retratándola líricamente como si fuera la primavera o la ninfa Flora ${ }^{51}$. El falso hortelano simula estar ocupado en sus faenas para disimular la sorpresa y los celos; más tarde cuando el segundo galán vuelve a apostrofarlo, le contesta de mala manera refunfuñando en habla rústica: «El dimuño os atiza. / Dejadme con mi trabajo; / que no me entiendo de amor» (pág. 398). Comentando posteriormente los sucesos con el criado, utiliza un lenguaje metafórico vinculado al mundo vegetal en sentido materialista y rebajado: «No sé qué habemos de hacer, / si tantos marchantes andan / para tan poca hortaliza» (ibíd.). En efecto, son tres los hombres que pretenden a Jacinta.

Luego, cuando la antigua amante, Lisarda, lo reconoce bajo su máscara, se da cuenta de que el ocultamiento no sólo ya no le sirve, sino que empieza a crearle más de un inconveniente. Su situación se complica aún más al principio del acto III cuando Jacinta, ignorante de la relación que existía entre su enamorado y Lisarda, viéndose obligada a explicar las razones que le impiden corresponder a don Luis, confiesa a la hermana de su aborrecido pretendiente su amor por don Carlos, narrándole las circunstancias de su encuentro azaroso:

51 «Buen hombre, que Dios te guarde, / y en verde hortaliza aumente, / ¿no sabes que todo oriente / viene a tu huerta esta tarde? / No sabes cómo Jacinta / viene a cubrilla de flores, / que son sus pies las colores / con que abril los prados pinta? / ¿Conócesla? Dime nuevas / de su hermosura y valor» (pág. 398). 


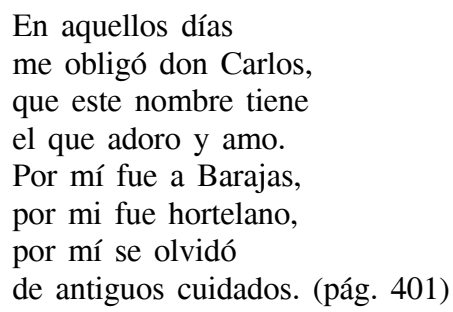

En las últimas macrosecuencias dramáticas, puesto que el disfraz de jardinero ha perdido toda vigencia, el galán protagonista recurre a otro engaño para casarse con Jacinta: hace, pues, que Lisarda sin saberlo se encierre en un aposento con su hermanastro Benito, mientras él se reúne con su amada en otra habitación. Al final, don Luis estará obligado a bendecir el casamiento de las dos parejas, quedando por su parte galán suelto.

Según he puesto de relieve en otro lugar, Hortelano, Benito y Don Carlos, cada cual a su manera, se relacionan con el tema de La Dorotea y son máscaras dramáticas de Lope, el cual las utiliza para autopromocionarse ante el público cortesano con el mismo juego de refracciones pictóricas que he aislado en Los ramilletes de Madrid ${ }^{52}$. También en este caso, el Fénix se autorretrata en clave burlesca, poniendo en solfa su más popular alter ego poético. El gracioso, mofándose de los humildes atuendos de su amo, le dice con chanza:

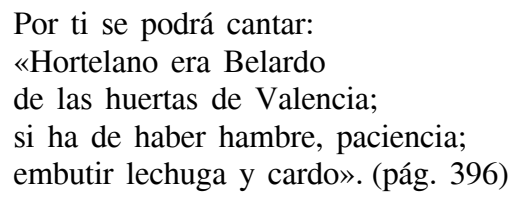

Más adelante, el mismo criado volverá a la pulla con una variante: «Hortelano era Belardo / de las huertas de Barajas» (pág. 398). Adviértase que el texto poético reitera hasta la saciedad la palabra «hortelano», ofreciendo el sinónimo «jardinero» sólo una vez. A fin de cuentas, Lope desea que su distinguido público esté obligado a fijar constantemente la atención en su propia figuración lírica, es decir, el hortelano Belardo, y diríase que con este objetivo recurre a una técnica propagandística que radica en la transmisión subliminal del mensaje.

En síntesis, las tres máscaras del Fénix en Al pasar del arroyo encarnan aspectos diferentes de la figura del jardinero de amor y, por su trámite, del mito lírico del madrileño. Hortelano, por su onomástica, remite de manera oblicua a Belardo; Benito es un héroe-villano que se expresa líricamente como un

\footnotetext{
${ }^{52}$ Cfr. Trambaioli, «Lope in fabula: el Fénix pintado por sí mismo en el marco dramático de su teatro cortesano», cit., págs. 552-553.
} 
pastor fino; estando enamorado en balde de Jacinta, al final renuncia al primer amor para casarse con otra, al igual que el Lope-Fernando de La Dorotea; además describe su huerta en términos idénticos a los que el dramaturgo utiliza en otras circunstancias para referirse a su propio jardincito:

\author{
Ya sabéis que yo no soy \\ pretendiente lisonjero, \\ porque más precio una flor \\ de un huertecillo que tengo, \\ que cuantas riquezas cubren \\ los doseles de sus techos. (pág. 393)
}

Finalmente, Don Carlos recurre al disfraz de hortelano para cortejar a la amada y, por esta malicia, resulta rebajado a nivel jocoso mediante la alusión al romance juvenil de Lope y el recurso estilístico al sayagués.

\title{
3.3. El hombre por su palabra
}

Con El hombre por su palabra, comedia palatina publicada en la Parte XX (1625) y surgida de la misma temperie coyuntural que produce Los ramilletes de Madrid y Al pasar del arroyo ${ }^{53}$, podemos constituir idealmente una trilogía dramática donde el recurso al jardinero postizo forma parte de las estrategias de autopromoción del Fénix.

Federico, que desde el principio de la obra hasta el cierre resulta ser el hijo del jardinero de palacio, es en realidad sobrino de Lisandro, rey de Macedonia. En la última macrosecuencia dramática el viejo hortelano Alberto confiesa haber trocado al protagonista con su propio hijo, Alejandro, aprovechándose de que su mujer era la nodriza del ilustre vástago. Federico es, pues, un héroe-villano que desconoce su identidad, al igual que Pedro en Los Ponces de Barcelona.

Dado que la fuerza de la sangre acaba siempre afirmándose, el mozo muestra inclinación por las armas y, pese a ser supuestamente un villano, consigue el permiso monárquico para marcharse a la guerra. El rey le tiene aprecio sin

\footnotetext{
${ }^{53}$ Según Morley y Bruerton, cit., pág. 341, la fecha de composición de esta obra es aproximadamente 1614-1615; si bien el texto dramático no presenta referencias a algún acontecimiento específico vinculado con las dobles bodas dinásticas coetáneas, la referencia final al «Senado» y varios aspectos de su factura dramática sufragan la hipótesis de que se trate de una de las muchas piezas del teatro de cámara del Fénix; cito por la versión digital de Parte Veinte de las comedias de Lope de Vega Carpio, en Madrid, por la viuda de Alonso Martín, a costa de Alonso Pérez, 1625, fols. 153-176 [BNE: R-13871], en Biblioteca Virtual Miguel de Cervantes; he modernizado la grafía y la puntuación.
} 
saber por qué: «Que tiene valor sospecho. / ¡Hola!, quitalde el sayal, / que es indigno de aquel pecho» ${ }^{54}$, y Federico conoce exactamente su objetivo:

De tu mano

con ese favor espero

trocar el ser de villano

en valor de caballero. (fol. 159v)

Como es de esperar, por sus capacidades bélicas gana el título de capitán y se cubre de gloria. A manera de recompensa, pide la mano de la mismísima infanta, Lucinda, y el rey, que es un hombre cabal, acaba por concedérsela, suscitando la envidia violenta de Alejandro, también enamorado de la dama, después de un sueño profético en el cual se le aparece la Historia entregándole un libro. El volumen contiene muchos ejemplos, bíblicos y legendarios, de hombres plebeyos que han ascendido al trono, entre otros,

Gordio de hortelano humilde

subió a la corona sacra;

Probo cultivó jardines;

Aurelio hortalizas varias. (fol. 172v)

A lo largo de toda la acción lo acompaña un criado, Fineo, que parodia su condición y vicisitudes. Por ejemplo, en el último acto, dice a Celia:

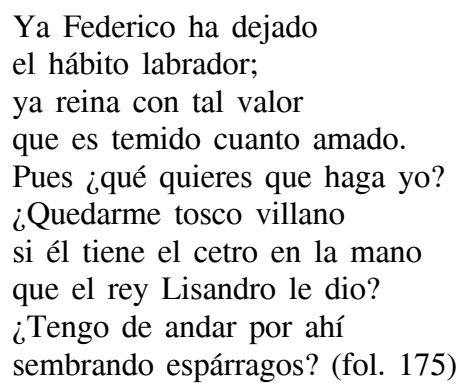

Pese a que, como queda dicho, el varón protagonista resulta ser al final de ilustre abolengo, porque la acción de la comedia tiene forzosamente que mantener el status quo, toda su actuación y sus reflexiones sirven en clave metateatral para reivindicar ante el público cortesano la dignidad de quien, como el dramaturgo, aun siendo de humilde nacimiento, sabe lucir dotes bélicas e inte-

${ }^{54} \mathrm{Y}$ al final, cuando sale a relucir la verdad, exclama: «No en vano tanto te amaba, / Federico, el alma mía; / mil veces mi cuello enlaza» (fol. 176v). 
lectuales. De hecho, Federico, además de ejercer con destreza el oficio de labrador, posee conocimientos históricos y filosóficos, es ducho en estrategia militar, y corteja a Lucinda en términos neoplatónicos ${ }^{55}$.

Adviértase que el nombre de la princesa, máscara poética de Micaela de Luján, sirve para relacionar al personaje con la fábula sentimental del propio Lope para que el público esté obligado a fijarse en las analogías metateatrales. Es irrelevante que los años de composición de la comedia no coincidan con la etapa de la relación amorosa correspondiente ${ }^{56}$, ya que el Fénix va elaborando su mito amoroso con variaciones, contradicciones y autoironías a lo largo de toda su azarosa existencia.

Federico presenta rasgos del escritor histórico también en relación con el idiolecto poético. Cuando al principio del I acto, se marcha para la guerra, despidiéndose líricamente de la huerta, dice: «Adios humilde aposento, / huésped de mis tiernos años»; ahora bien, al principio del I canto de La hermosura de Angélica, el yo poético en clave autobiográfica se dirige a Lucinda utilizando el mismo sintagma: «Que en él ardiendo aquel humilde ingenio, / que os consagré desde mis tiernos años» ${ }^{57}$. También, en el II acto, el protagonista de El hombre por su palabra, cortejando en hábitos de jardinero a la princesa, alude al famoso romance «Sale la estrella de Venus» ${ }^{58}$, que en el marco de la literaturización de los amores lopeveguescos se vincula a Elena Osorio, como si se tratara del propio Belardo del romancero pastoril.

Finalmente, la desilusión hacia la corte que Federico expresa en varias ocasiones anda pareja con las lamentaciones del jardinero Fabio en El premio de la hermosura; en concreto, ambos se quejan de la falta de reconocimiento en patria. Dice Fabio:

Canté desde que nací

de Júpiter español

\footnotetext{
${ }^{55}$ Dice Federico en el acto II en una escena de galanteo en la huerta: «Mírase como un espejo / en vos el alma, y los dos / vivimos en mí y en vos, / porque mi retrato os dejo, / y sin morir puede ser / daros el alma» (fol. 166).

56 Courtney Bruerton, «Lope’s Belardo-Lucinda Plays», Hispanic Review, V, 1937, pág. 313, señala que hay comedias como ésta con un personaje llamado Lucinda que resultan compuestas después del periodo de los amores del poeta con Micaela de Luján (1599-1608).

${ }^{57}$ Lope de Vega, La hermosura de Angélica, Marcella Trambaioli, ed., Madrid/ Frankfurt am Main, Iberoamericana/ Vervuert, 2005, pág. 198, vv. 9-10; se trata de una traducción de la frase latina a teneris ungulis a la cual Lope recurre también en Fiestas de Denia, Maria Grazia Profeti, ed., Firenze, Alinea, 2004, pág. 102, vv. 785-786: «No me permite amor, que fue castigo / del cielo en mí desde mis años tiernos».

58 «Aquí la blanca estrella / que del carro de Venus Vespertina / es la paloma bella...» (fol. 167); el romance aludido fue muy popular por lo menos hasta la década de los '40, con el acompañamiento musical de Torrejón y Velasco; véase Miguel Querol Gavaldá, La música en la obra de Cervantes, Alcalá de Henares, Ediciones del Centro de Estudios Cervantinos, 2005, págs. 96-97.
} 
las grandezas, y hasta el sol mi humilde plectro subí, y no he merecido ser su coronista siquiera, y de la tierra extranjera otros me vienen a ver ${ }^{59}$.

De forma análoga suspira escéptico Federico:

$$
\begin{aligned}
& \text {... nadie es profeta en patria } \\
& {[\ldots]} \\
& \text { Y el que mil naciones honran, } \\
& \text { si de letras o armas trata, } \\
& \text { veréis que en su patria ingrata } \\
& \text { le infaman y le deshonran... }
\end{aligned}
$$

La diferencia estriba en que el primero, como ya recordado, se dirige a los miembros de la corte por cuenta de Lope para pedir el puesto de cronista real, mientras que el segundo mantiene una línea argumentativa más general, recurriendo a la técnica del decir sin decir, con un objetivo claramente idéntico.

\section{LA VUELTA AL JARDINERO DE AMOR EN LA ÉPOCA DE SENECTUTE: NO SON TODOS RUISEÑORES}

Sabido es que el poeta no consigue el cargo tan ambicionado de cronista regio; por lo mismo en la última fase de su carrera teatral no vuelve a pisar las tablas disfrazado de jardinero para autopromocionarse. Más aún: por varios años la figura del hortelano postizo pierde vigencia en sus comedias.

Llegamos, pues, a la última obra del corpus recogido: No son todos ruiseñores $(1630)^{60}$, comedia de capa y espada ambientada en Barcelona con una densa red de referencias coyunturales a los fastuosos festejos monárquicos celebrados por el nacimiento del príncipe Baltasar Carlos y por el matrimonio de la infanta María de Austria con el futuro emperador Fernando III.

Los regocijos públicos coinciden, para mayor abundamiento, con la época del Carnaval. Aprovechando la atmósfera relajada de los festejos callejeros, Leonarda, en compañía de su prima Marcela, va a buscar a don Juan, caballero castellano

\footnotetext{
59 Cito por Obras de Lope de Vega, XXIX, Comedias novelescas, Marcelino Menéndez Pelayo, ed., Madrid, Atlas, 1970, [B.A.E., 234], pág. 394.

${ }^{60}$ Cito por No son todos ruiseñores, en Obras de Lope de Vega, XXXII, Comedias novelescas, Marcelino Menéndez Pelayo, ed., Madrid, Atlas, 1972, págs. 137-184.
} 
conocido azarosamente en la playa, llevando una mascarilla ${ }^{61}$, Lisardo revela a su amigo que la dama, siendo una señora muy principal, está dispuesta a aceptar su galanteo a condición de que vaya a verla «como máscara» (pág. 140).

Llegan a casa de Leonarda dos hombres disfrazados, don García y don Pedro, para cortejar a las dos primas; justo después entran don Juan y Lisardo, también enmascarados; el primero confiesa sus celos a la dama, porque se percata de que aquéllos que los han precedidos «Son máscaras del amor, / que con ellos se disfraza» (pág. 145). El protagonista, formando parte de la compañía regia, en una larga relación de la entrada triunfal de la princesa, confiesa no quererse partir de la ciudad condal rumbo a Hungría, por haberse prendado de Leonarda. Adviértase que el hecho de ser portavoz de las instancias encomiásticas del autor en el caso de don Juan no implica la proyección autobiográfica señalada en las comedias de la madurez.

En el cierre de la I jornada los dos enamorados prometen que volverán a verse pronto aún gracias a un disfraz ${ }^{62}$. La máscara que permite al galán castellano introducirse en el palacio de la dama es, como es de esperar, la del jardinero de amor: al principio del II acto, pues, según reza la acotación «sale don Juan, de labrador, soldado, con capote de dos haldas, espada y daga, y Cosme, villano, jardinero» (ibíd.). El noble, fingiéndose primo del verdadero hortelano, cuenta a éste que, desde pequeño, se había marchado pasando por muchos trabajos. La simultánea salida al escenario de los dos personajes hace visualmente hincapié en la diferencia estamental que los separa y en la doble personalidad de don Juan, ya que el hábito de éste es más bien propio de un militar que de un labrador. Ello no obstante, el galán consigue engatusar a Cosme de tal manera que éste termina por asumir el parentesco con el falso Pedro, presentándolo como primo a su mujer Elvira y confiándole el cuidado del jardín.

Ya solo en el escenario, don Juan invoca a Cupido, aludiendo de forma implícita a su estatuto de hortelano de amor: «A tu jardín he venido; / ayúdame, pues me diste / la traza» (pág. 154). Por su parte, la esposa de Cosme, favorablemente impresionada por el talle del primo desconocido y, sobre todo, por la sortija que éste le ha regalado, queda de alguna manera transformada en su esencia rústica, expresándose con tonalidades líricas impropias de su baja condición, al contrario del marido que salpica su discurso con formas lingüísticas del sayagués ${ }^{63}$.

${ }^{61}$ Dice Leonarda a Marcela en la primera macrosecuencia del acto inicial: «El tiempo, la confusión / de propios y forasteros, / el vulgo, los caballeros, / tanta gala e invención, / no dejarán reparar / en el disfraz que traemos» (pág. 138); más adelante, hablando con su hermano Fernando, reitera: «No hay en la ciudad persona / que no se alegre y disfrace» (pág. 142).

${ }^{62}$ Leonarda: «¿Disfrazaros queréis?»; Juan: «Sí» (pág. 151).

${ }^{63}$ Recita Elvira en su soliloquio: «Hoy amaneció más claro / en este jardín el sol, / que no fue de su arrebol / anoche el ocaso avaro [...]» (pág. 154); en cambio, Cosme, un poco mas adelante, usa la deformación del adjetivo posesivo típica del pastor bobo: «a nueso primo» (pág. 155). 
Cosme revela a su ama que está hospedando a un primo soldado, y ella no tarda en reconocerlo porque estaba esperando que el pretendiente apareciera en su casa disfrazado. Entrevistándose con el amado, Leonarda se muestra agradecida por la «amorosa fineza» que conlleva un rebajamiento temporáneo de su persona:

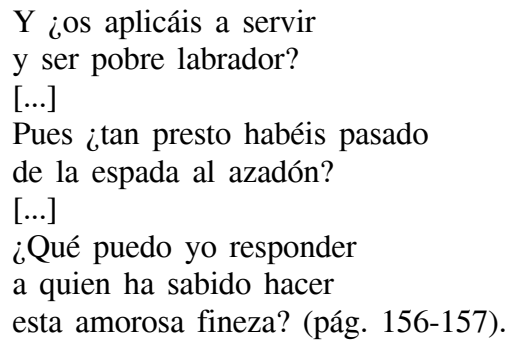

Juan remacha su condición de jardinero de amor, invocando las flores como testigos de la correspondencia sentimental ${ }^{64}$. Tras lo cual, la llegada de Fernando, el hermano de la dama, produce una situación análoga a la de Los ramilletes de Madrid: el falso hortelano tiene que demostrar al dueño del jardín sus conocimientos profesionales para llevar a cabo las reformas adecuadas y ganarse su confianza.

Al no estar presente Cosme en el escenario, don Juan asume algunas connotaciones propias del humilde tipo teatral correspondiente, expresándose con rasgos del habla rústica: «Pardiez, muesamo» (pág. 158). Pero hay un elemento inédito: es decir, hasta el noble catalán certifica su personal afición a la jardinería: «aquí tardes y mañanas / me veréis ejercitando / el escardillo y la azada» (pág. 159). Esta larga macrosecuencia dramática se cierra con un soneto declamado por el protagonista con un lirismo propio de la figura del hortelano de $\operatorname{amor}^{65}$.

El resto de la jornada intermedia acumula varios obstáculos a la realización del casamiento entre don Juan y Leonarda: por un lado, don García pretende a la dama; por otro, Elvira empieza a acosar sexualmente al galán, provocando los celos del marido. En este sentido, Lope opta por desarrollar una situación dramática que sólo había esbozado en El soldado amante, complicándola ulteriormente, ya que, según queda dicho, no es la hija, sino la mujer del jardinero

\footnotetext{
${ }^{64}$ «Flores de aqueste jardín, / y vos, florido arrayán, / claveles, favor me dan: / imprimid tales favores / en las hojas de colores, / para que entre estos claveles, / favores que dan laureles / impriman hojas de flores. / Sed testigos [...]» (pág. 158).

65 «Creced las flores blancas y encarnadas, / almendros, como crecen mis favores, / juntemos esperanzas bien fundadas; / que como en una cáscara dos flores / engendran dos almendras abrazadas / abrazarán dos almas dos amores» (pág. 160).
} 
quien se enamora del hortelano fingido. Así el noble disfrazado se queja en aparte por el acoso: «¿Qué me quiere aquesta sombra / que siempre me va persiguiendo?» (pág. 162), mientras la labradora lamenta sus desdenes con un lenguaje que, de nuevo, la acerca al registro elevado de aquél:

Pedro, piedra para mí, ¿cuándo ha de ser aquel día que mi esperanza y porfía hallen acogida en ti? (ibíd.)

Si la providencial intervención de Cosme consigue alejar a la mujer, a la vez pone al descubierto la presunta rivalidad entre los dos hombres. Fijémonos en que, en su rústico discurso, Cosme alude al motivo de los cuernos con una imagen conforme al registro cómico-burlesco que consigue rebajar al tipo del jardinero:

\author{
Hay cierto signo en el cielo \\ que le llaman Capricornio, \\ que reina sobre hortelanos \\ a veinte y cuatro de agosto. (pág. 163)
}

Quedando solo en el escenario, Juan aprovecha para analizar su complicada situación: si por la noche, gracias a la ayuda de Lisardo, consigue hablar a Leonarda «vestido galán y rico» (pág. 164), de día padece el acoso de Elvira disfrazado de hortelano. Como si no bastara, Fernando le pide ayuda para prender al hombre que se entretiene de forma clandestina con su hermana. Para salir de apuros, le engaña con la verdad, diciéndole que él mismo irá a entrevistarse con Leonarda, fingiendo ser el galán misterioso para que ella, ingenuamente, le revele su identidad; pero ya se ha puesto de acuerdo con la dama para que mencione su verdadero nombre: don Juan de Peralta. De esta manera, consigue adelantar al futuro cuñado la identidad del que acabará casándose con su hermana, teniendo la oportunidad de hablar con ella en su presencia.

Antes de que el acto se cierre, vuelven a pisar las tablas Elvira y Cosme, cada uno por separado, pero ambos vestidos con capa y espada, parodiando el enredo principal: si la labradora, celosa, sigue a don Juan hasta las rejas de su ama, el marido va tras ella para averiguar si lo traiciona con el presunto primo. Desde luego, el disfraz de los dos rústicos sirve para crear un jocoso contrapunto dramático con respecto a la máscara de jardinero de amor del noble don Juan.

La III jornada se abre con una lírica entrevista nocturna entre los dos protagonistas, que anticipa el desenlace esperado. Pero antes de llegar al final feliz, el texto dramático ofrece nuevas desavenencias a la pareja de amantes. Fernan- 
do, ante su hermana, regaña al jardinero fingido por haber pretendido a Elvira, dando escucha a las quejas de Cosme, y la dama se lo cree, identificando así por un momento al noble castellano con su indigna máscara rústica. Juan queda, pues, despedido por su amada, perseguido por Elvira y, encima, acusado por Fernando de haber manchado la reputación de su casa. El noble catalán declara contundente: «Reformar quiero mi casa; / los pícaros jardineros / han de salir los primeros» (pág. 178) y, tras echar a Cosme y Elvira con unos ecos paródicos de la despedida de Adán y Eva del Edén ${ }^{66}$, quisiera hacer lo mismo con el falso Pedro, pero éste le promete entregarle a don Juan. La comedia se cierra con la salida al escenario del noble castellano, «de galán, con hábito, y de la mano Leonarda» (pág. 183) declarando su verdadera identidad y las razones de su ocultamiento:

No Pedro, si bien por ella
fui los días que sabéis
labrador de aquesta huerta.
Si la muerte ha merecido
esta amorosa fineza,
aquí estoy. (ibíd.)

Tratándose de una pieza cómica, tanto a Fernando como a don García no queda más remedio que aceptar el casamiento de don Juan y Leonarda.

\section{CONCLUSIÓN}

Montesinos, en su rastreo de las fuentes de algunas comedias lopeveguescas, había señalado unas analogías entre Los Ponces de Barcelona, Los ramilletes de Madrid y No son todos ruiseñores, fijándose de soslayo en la figura del jardinero fingido ${ }^{67}$. Curiosamente la primera y la tercera, junto con el Abanillo, ambientan gran parte de la acción en Barcelona, y son obras de trasfondo ciudadano, aun con contaminaciones de otros subgéneros dramáticos. Con evidencia, Lope se da cuenta de que la figura del falso hortelano resulta dramáticamente más fértil y sugerente en la comedia de enredo de ambientación urbana

\footnotetext{
${ }^{66}$ Cosme dice a su antiguo amo: «Pareces en el jardín / el ángel de Adán y Esgueva» (pág. 180), y a su mujer: «Vos tenéis la culpa, Elvira; / por vos de casa nos echan»; por su parte, la labradora contesta: «Eso sí, siempre tenemos / de cualquier cosa siniestra / culpa todas las mujeres: / yo, imitando a la primera, / a la sierpe se la doy» (pág. 182); por cierto, a la postre no parece casual que en el nombre de Elvira esté incluido el de la primera mujer.

${ }^{67}$ José F. Montesinos, Estudios sobre Lope de Vega, Salamanca/ Madrid/ Barcelona/ Caracas, Anaya, 1967, págs. 92-93; el crítico señala además La amistad y obligación que, de todas formas, es una comedia de incierta autenticidad.
} 
y coetánea que en la palatina, porque crea un marcado contraste entre el mundo familiar en que se mueven los personajes y el universo arcádico al cual remite el tipo teatral. Así pues, si es cierto que tras la etapa primeriza Lope ya no compone piezas pastoriles, hecha salvedad de La Arcadia y de La selva sin amor, a través del jardinero fingido tiene la oportunidad de insertar en su teatro maduro fragmentos poéticos dignos de figurar en una novela o en un drama pastoril.

Por lo visto, sus hortelanos postizos presentan aspectos tanto del pastor fino como del rústico aldeano, según prevalezca el lirismo del galanteo amoroso, o el rebajamiento del personaje debido al engañoso cambio estamental. En dos casos, el de Los Ponces de Barcelona y el de El hombre por su palabra, el tipo del falso jardinero coincide con la figura del héroe-villano. Cierto es que el disfraz rústico da pie a una serie notable de posibilidades dramáticas que giran en torno al tema del engaño y al ocultamiento o suplantación de la identidad.

Por último, cabe destacar que todas estas comedias forman parte del repertorio de cámara con el cual el Fénix regocija la nobleza y en ocasiones hasta la familia real en festejos privados. A este respecto, hace falta destacar que el jardinero fingido no sólo satisface y refleja los gustos literarios del público aristocrático, sino que alrededor de 1615 resulta funcional al poeta como máscara adecuada para romper la ilusión dramática y dirigirse a sus ilustres espectadores para autopromocionar sus ambiciones personales. Resulta emblemático que en la última comedia analizada ya de la época de senectute Lope no connote la figura del falso hortelano con instancias autopropagandísticas. Es un hecho que en 1629 había visto esfumarse la última esperanza de conseguir el tan ambicionado puesto de cronista de la Corona, que se llevó Pellicer. ${ }^{68} \mathrm{El}$ viejo poeta se limita, pues, a conformar el tipo del jardinero postizo revitalizando todos los elementos temáticos y estilísticos que había elaborado en piezas anteriores, con algunos aspectos inéditos y el desarrollo de situaciones en ciernes. Así, el hortelano fingido vuelve a ser jardinero de amor y máscara rústica, pero ya no figuración dramática del Fénix de los Ingenios quien, a estas alturas, se contenta con cuidar su huertecilla de la calle de Francos fuera de la ficción teatral.

\section{BIBLIOGRAFÍA}

Álvarez Sellers, María Rosa, «Príncipes disfrazados y estrategias de pasión: Don Duardos de Gil Vicente, El príncipe viñador de Vélez de Guevara y La venganza de Tamar de Tirso de Molina», en M. L. Lobato, ed., Máscaras y juegos de identidad en el teatro español del Siglo de Oro, Madrid, Visor Libros, 2011, págs. 261-277.

${ }^{68}$ Vid. Juan Manuel Rozas, Estudios sobre Lope de Vega, Madrid, Cátedra, 1990, pág. 82. 
Antonucci, Fausta, El salvaje en la comedia del Siglo de Oro. Historia de un tema de Lope a Calderón, Pamplona, Toulouse, RILCE, LESO, 1995.

Arata, Stefano, Textos, géneros, temas. Investigaciones sobre el teatro del Siglo de Oro y su pervivencia, F. Antonucci, L. Arata y M. del Valle Ojeda, eds., Pisa, Edizioni ETS, 2002.

Arellano, Ignacio, Convención y recepción. Estudios sobre el teatro del Siglo de Oro, Madrid, Gredos, 1999.

Bruerton, Courtney, «Lope’s Belardo-Lucinda Plays», Hispanic Review, V, 1937, págs. 309-315.

Buezo, Catalina, «Hacia una tipología del villano y lo villano en el teatro áureo», en F. B. Pedraza Jiménez, R. González Cañal y E. Marcello, eds., La comedia villanesca y su escenificación, Actas de las XXIV Jornadas de Teatro Clásico, Almagro, 10-12 de julio de 2001, Almagro, Universidad de Castilla La-Mancha, Festival de Almagro, 2002, págs. 297-319.

Case, Thomas E., Las dedicatorias de Partes XIII-XX de Lope de Vega, Madrid, Castalia, Department of Romance Languages, University of North Carolina, 1975.

Egido, Aurora, «Jardín-libro» y «Libro-jardín», en P. Soto de Rojas, Paraíso cerrado para muchos, jardines abiertos para pocos, Madrid, Cátedra, 1993, págs. 22-46.

Egido, Aurora, «Escritura y poesía. Lope al pie de la letra», Edad de Oro, XIV, 1995, págs. 121149.

Eiroa, Sofía, «Los villanos fingidos en Tirso de Molina: técnicas dramáticas y su representación», en F. B. Pedraza Jiménez, R. González Cañal y E. Marcello, eds., La comedia villanesca y su escenificación, Actas de las XXIV Jornadas de Teatro Clásico, Almagro, 10-12 de julio de 2001, Almagro, Universidad de Castilla La-Mancha, Festival de Almagro, 2002, págs. 237254.

Góngora, Luis de, Sonetos completos, Biruté Ciplijauskaité, ed., Madrid, Clásicos Castalia, 1987.

Lanot, Jean-Raymond, «Para una sociología del figurón», en Groupe d'études sur le théâtre espagnol, eds., Risa y sociedad en el teatro español del Siglo de Oro, Paris, Éditions du C.N.R.S., 1981, págs. 131-151.

McGrady, Donald, «Prólogo», en Lope de Vega, Peribáñez y el Comendador de Ocaña, Barcelona, Crítica, 1997, págs. LVII-CXXXV.

Montesinos, José F., Estudios sobre Lope de Vega, Salamanca, Madrid, Barcelona, Caracas, Anaya, 1967.

Morley, Griswold y Bruerton, Courtney, Cronología de las comedias de Lope de Vega, Madrid, Gredos, 1968.

Oleza, Joan, «La propuesta teatral del primer Lope de Vega», Cuadernos de Filología, III, 1- 2, 1981, págs. 153-223.

Oleza, Joan, «La tradición pastoril en la comedia de Lope de Vega», en J. L. Canet Vallés, ed., Teatro y prácticas escénicas. II: La comedia, London, Tamesis, 1986, págs. 325-343.

Petrarca, Francesco, Rime, Guido Bezzola, ed., Andrea Zanzotto, introd., Milano, RCS Rizzoli Libri, 1976.

Profeti, Maria Grazia, «Essere vs apparire nel teatro barocco», en I. Pepe Sarno, ed., Dialogo. Studi in onore di Lore Terracini, Roma, Bulzoni Editore, 1990, vol. II, págs. 543-555.

Profeti, Maria Grazia, «Luogo teatrale e scrittura: il teatro di Juan del Encina», en M. G. Profeti, La vil quimera de este monstruo cómico, Kassel, Università di Verona, Ed. Reichenberger, 1992, págs. 3-20.

Profeti, Maria Grazia, «I viaggi di un principe giardiniere», en M. J. de Lancastre, S. Peloso, U. Serani y R. Antonelli, eds., E Vós, Tágides Minhas: Miscellanea in onore di Luciana Stegagno Picchio, Viareggio, Mauro Baroni, 1999, págs. 523-540.

Querol Gavaldá, Miguel, La música en la obra de Cervantes, Alcalá de Henares, Ediciones del Centro de Estudios Cervantinos, 2005.

Robert Curtius, Ernst, «El libro de la naturaleza», en E. Robert Curtius, Literatura europea y Edad Media Latina, México, Fondo de Cultura Económica, 1955, vol. I, págs. 448-457. 
Roso Díaz, José, Tipología de engaños en la obra dramática de Lope de Vega, Cáceres, Universidad de Extremadura, 2002.

Rozas, Juan Manuel, Estudios sobre Lope de Vega, Madrid, Cátedra, 1990.

Salomon, Noël, Recherches sur le thème paysan dans la «comedia» au temps de Lope de Vega, Bordeaux, Institut d'Études Ibériques et Ibéro-Américaines de l'Université de Bordeaux, 1965.

Segre, Cesare, «Shakespeare e la «scena en abyme»», en C. Segre, Teatro e romanzo, Torino, Einaudi, 1984, págs. 51-60.

Serés, Guillermo, La transformación de los amantes. Imágenes del amor de la antigüedad al Siglo de Oro, Barcelona, Crítica, 1996.

Soto de Rojas, Pedro, Paraíso cerrado para muchos, jardines abiertos para pocos, Madrid, Cátedra, 1993.

Spitzer, Leo, «Soy quien soy», Nueva Revista de Filología Hispánica, 1, 2, 1947, págs. 113-127.

Trambaioli, Marcella, «Valores poéticos y funciones escénicas del eco en las fábulas mitológicas de Calderón», en M. Tietz, ed., Deseo, sexualidad y afectos en la obra de Calderón, Duodécimo Coloquio Anglogermano sobre Calderón (Leipzig, 14-18 de julio de 1999), Stuttgart, Franz Steiner, 2001, págs. 181-200.

Trambaioli, Marcella, «Una pre-Dorotea circunstancial de Lope de Vega: Los ramilletes de Madrid. I. Análisis estructural», en O. Gorsse y F. Serralta, eds., El Siglo de Oro en escena. Homenaje a Marc Vitse. [Anejo de Criticón, 17], Toulouse, Presses Universitaires du Mirail, Conserjería de Educación de la Embajada de España en Francia, 2006, págs. 1.037-1.048.

Trambaioli, Marcella, «Una pre-Dorotea circunstancial de Lope de Vega: Los ramilletes de Madrid. II. Las polémicas literarias y la dimensión política», Criticón, 96, 2006, págs. 139-152.

Trambaioli, Marcella, «El galán suelto y el figurón en Los Ponces de Barcelona de Lope de Vega», Nueva Revista de Filología Hispánica, LVI, 2, 2008, págs. 489-504.

Trambaioli, Marcella, «Lope de Vega y la casa de Moncada», Criticón, 106, 2009, págs. 5-44.

Trambaioli, Marcella, «Las dobles bodas reales de de 1615: el triunfo del Lope-personaje sobre el Lope cortesano», Bulletin of Hispanic Studies, vol. 87, 7, 2010, págs. 755-772.

Trambaioli, Marcella, «En torno al doble estatuto dramático de Lucrecia en Los Ponces de Barcelona de Lope de Vega», Theatralia, XII, Homenaje a María Grazia Profeti, 2010, págs. 83100.

Trambaioli, Marcella, «Lope in fabula: el Fénix pintado por sí mismo en el marco dramático de su teatro cortesano», en E. Llergo e I. Osuna, eds., Cultura visual, oral y escrita en la España de los Siglos de Oro (II Seminario GLESOC, Universidad Complutense de Madrid, 27-28 de octubre de 2009), Madrid, Visor Libros, 2010, págs. 537-563.

Trambaioli, Marcella, «"Aquí Senado se acaba...”: normas implícitas y rasgos dramáticos del teatro de cámara de Lope de Vega», en G. Poggi y M. G. Profeti, eds., Norme per lo spettacolo / Norme per lo spettatore. Teoria e prassi del teatro intorno all "Arte Nuevo", Firenze, Alinea Editrice, 2011, págs. 185-198.

Trambaioli, Marcella, «Variaciones sobre el motivo del jardinero fingido en la escritura de Calderón, Moreto y su escuela dramática», en M. L. Lobato, Máscaras y juegos de identidad en el teatro español del Siglo de Oro, Madrid, Visor Libros, 2011, págs. 95-111.

Vega, Lope de, El hombre por su palabra, en Parte Veinte de las comedias de Lope de Vega Carpio, Madrid, por la viuda de Alonso Martín, a costa de Alonso Pérez, 1625, fols. 153-176 [BNE: R-13871], en Biblioteca Virtual Miguel de Cervantes.

Vega, Lope de, El abanillo, en Obras de Lope de Vega, III, Emilio Cotarelo, ed., Madrid, R.A.E., 1917, págs. 1-32.

Vega, Lope de, El soldado amante, en Obras de Lope de Vega, IX, Emilio Cotarelo, ed., Madrid, R.A.E., Tipografía de Archivos, 1930, págs. 552-589.

Vega, Lope de, Los ramilletes de Madrid, en Obras de Lope de Vega, Obras dramáticas, XIII, Emilio Cotarelo, ed., Madrid, R.A.E., 1930, págs. 469-504. 
Vega, Lope de, Al pasar del arroyo, Comedias escogidas de frey Lope Félix de Vega Carpio, Juan Eugenio Hartzenbusch, ed., Madrid, Atlas, 1946, págs. 387-407.

Vega, Lope de, El jardín de Lope de Vega y otras epístolas, Obras selectas, Federico Carlos Sáinz de Robles, ed., Madrid, Aguilar, 1947.

Vega, Lope de, No son todos ruiseñores, en Obras de Lope de Vega, XXXII, Comedias novelescas, Marcelino Menéndez Pelayo, ed., Madrid, Atlas, 1972, págs. 137-184.

Vega, Lope de, El peregrino en su patria, Juan Bautista Avalle-Arce, ed., Madrid, 1973.

Vega, Lope de, El acero de Madrid, Stefano Arata, ed., Madrid, Castalia, 2000.

Vega, Lope de, Fiestas de Denia, Maria Grazia Profeti, ed., Firenze, Alinea, 2004.

Vega, Lope de, La hermosura de Angélica, Marcella Trambaioli, ed., Madrid, Frankfurt am Main, Iberoamericana, Vervuert, 2005.

Vega, Lope de, Rimas humanas y divinas del licenciado Tomé de Burguillos, José Manuel Rozas y Jesús Cañas Murillo, eds., Madrid, Castalia, 2005.

Vega, Lope de, Los Ponces de Barcelona, Marcella Trambaioli, ed., en Comedias de Lope de Vega. Parte IX, Barcelona-Lleida, PROLOPE, UAB-Editorial Milenio, 2007, vol. III, págs. 1.053-1.149.

Zugasti, Miguel, «El jardín: espacio del amor en la comedia palatina. El caso de Tirso de Molina», en F. Cazal, C. González y M. Vitse, eds., Homenaje a Frédéric Serralta. El espacio y sus representaciones en el teatro español del Siglo de Oro, Actas del VII Coloquio de GESTE (Toulouse, 1-3 de abril de 1998), Madrid, Frankfurt am Main, Universidad de Navarra, Iberoamericana, Vervuert, 2002, págs. 583-619.

Fecha de recepción: 13 de septiembre de 2010

Fecha de aceptación: 21 de diciembre de 2010 